This PDF is a selection from an out-of-print volume from the National Bureau of Economic Research

Volume Title: The Role of Middleman Transactions in World Trade

Volume Author/Editor: Robert M. Lichtenberg

Volume Publisher: NBER

Volume ISBN: 0-87014-378-6

Volume URL: http://www.nber.org/books/lich59-1

Publication Date: 1959

Chapter Title: Conclusions and Comments

Chapter Author: Robert M. Lichtenberg

Chapter URL: http://www.nber.org/chapters/c2566

Chapter pages in book: (p. 73 - 80) 


\section{Conclusions and Comments}

\section{Conclusions}

This investigation of middleman trade indicates that the bulk of world trade is direct. Records for 1952 of seven mainly Western European countries, which report imports by country of production and country of purchase, supplemented by rougher quantitative material on other countries, show that middleman countries supply 13 percent of their imports by simple average and 16 percent by weighted average.

On the basis of the data supplied by these countries and of some assumptions about the rest of the world trade, world middleman trade may be tentatively estimated at about 13 percent of the total for 1952 . This estimate takes into account concentration of middleman trade by commodity and by country of origin, the probably relatively low proportion of imports of middleman countries purchased from middlemen, and the probably relatively small volume of middleman trade between neighboring countries. Nevertheless, the estimate, dominated by the experience of a small group of countries chosen for availability of their records, not as representative, must be considered distinctly preliminary.

Imports purchased from middlemen appear to be concentrated, relative to total imports, in primary and semimanufactured goods. This is particularly the case in the categories: crude and semimanufactured minerals, fertilizers, and fuels; rubber and rubber products; beverages, tobacco, sugar, and fodder. Purchases from middlemen are relatively small in machinery, transportation equipment, and chemical and pharmaceutical products.

Middlemen reside primarily in a few industrial countries of Western Europe, in the United States, and in their outlying entrepôt centers, for example Hong Kong. The U.K. is the major middleman country, selling over 40 percent of imports purchased from middleman countries by each of the seven countries, except Colombia. Next, in decreasing order of magnitude of middleman trade, are the U.S., France, and the Netherlands. The importance to the middleman countries of their middleman activities varies considerably. The U.K., ranking high among world traders, not only ranks first among the major middleman countries, but also has the highest ratio of sales of other countries' produce to sales of its own produce - on average 75 percent of its total domestic exports in 1952. Other countries for which their own middleman trade was relatively important in total trade in 1952 are France (36 percent), Switzerland (27 percent), the Netherlands (22 percent) and the U.S. (17.5 percent).

A major part of the exports of Asia and Africa (excluding the sterling 
dominions and the Soviet bloc) and of Canada goes to the seven final importing countries via middlemen. There is evidence that imports of some of these countries also come via middlemen, aside from imports by own overseas territories of produce of the corresponding metropole. German and Danish figures show Western European metropoles selling a high percentage of the products of their own overseas territories, but also that this is less than half of total middleman trade. Middleman countries also sell each other's produce to third countries. Our data show, in weighted average, these sales to be about one-fifth of total middleman trade but only a small percentage of total domestic or special exports of the middleman countries.

Examination of some of the major components of middleman trade gave evidence, first, from the selected importing countries and the British overseas territories that only a small part of their own exports and of their imports are handled by native merchants in overseas territories. Most overseas territorial trade is controlled by metropole interests, making this type of middleman trade a high proportion of total trade for those countries, such as Malaya in its colonial status, which have relatively small exports to the metropole. For the U.K. dependencies and more recent commonwealth members, there is also evidence of a high concentration of trade in a few British companies which, except in West Africa, are concerned, beyond buying and selling, with most aspects of production and distribution, often in several territories. They have thus strengthened their position through economies of coordinating multinational production and distribution from a world commercial center. But as colonies achieve independence they curtail British activities both for political reasons and to increase their share of profits from distribution.

Middlemen also play an important role in the international distribution of hard currencies in their switch trade activities. These activities are only a small part of world trade; as indicated by German and Danish import records, they are perhaps no more than one-quarter of middleman trade. The importance of this second component derives from the usefulness of switch trade as a safety valve in bilateral agreements, its value as an indicator of disequilibrium, and its volume in relation to the current dollar balance for some countries. The activities of the continental powers and the U.K. in this form of middleman activity in the postwar period either have been welcomed as a means of introducing flexibility into bilateral payments agreements or have led to sharp reactions by governments, frequently in the direction of liberalizing discriminatory regulations. Thus, in reaction to switch trade, the Bank of England decided in 1955 to support the transferable sterling rate, thereby establishing de facto convertibility. 
A third component of middleman trade, entrepôt trade, which played an important role historically in the commercial supremacy of a succession of nations, is a minor part of middleman activities of major middleman countries, except in outpost parts of these countries, such as Hong Kong, and has been a declining part of their total trade in the twentieth century. Economic development, particularly in the fields of transportation, communication, and market organization, has reduced the need for entrepôt trade. Factors tending to reduce entrepôt trade also apply, though not as strongly, to offshore merchanting, which is apparently replacing entrepôt trade to some extent.

These aspects of middleman activity have some interesting implications for the interpretation of trade and payments records of countries which in general do not reveal offshore merchanting. Most countries represent their trade reports to be by country of origin for imports and country of final destination or consignment for exports, but records are generally carried over into the balance of payments accounts without adjustment to purchase-sale. Thus, on the one hand, the high concentration that we found for middleman trade in certain middleman countries, in producing countries, and in some commodities means that using trade and payments records to assess the interregional financial position of a country results in serious distortions. And, on the other hand, evidence of relatively low reconsignment trade by major industrial middlemen, except in their outposts, suggests that the trade records are generally useful for origindestination analysis. This is well illustrated by four commodities petroleum, coffee, rubber, and cotton - each of which provides most of the exports of several countries. Countries' export and corresponding import records of trade in these commodities generally disclose the countries of production and consumption of the commodities (major exceptions being records of trade with outposts of middleman countries and records of the few countries using the purchase-sale system of reporting partner countries). But these records do not, for the most part, reflect the changing interregional position of the middleman in relation to the producing or final consuming countries.

\section{Proposals by International Organizations on Recording Middleman Trade}

In October 1952 a group of United Nations experts presented a set of proposals designed to improve the recording of international trade statistics, ${ }^{1}$ the first major attempt since the League of Nations conven-

1 Principles for Statistics of External Trade, United Nations Document E/CN.3/142, October 6, 1952. 
tion of $1928 .^{2}$ The International Monetary Fund commented on the U.N.'s proposals, suggesting some revisions, and is believed to have considered incorporating part of them in a revision of the Balance of Payments Manual. $^{3}$ So far neither the experts' report nor the IMF Manual revision has been adopted, and both are, of course, subject to further revision. The chief interest, therefore, in these documents is their relevance to current thinking on the subject by experts in the field. The objectives of the international organizations, not sharply defined, include improvement in comparability of recording any given transaction by the exporter and importer. Neither the U.N. nor the IMF states explicitly that one objective is to reveal middleman trade, but suggestions offered by both indicate an underlying interest in it. For discussion, the relevant proposals can be divided into those to adjust systems of reporting partner countries, and those to adjust trade classification systems.

The U.N. proposal concerning reporting of partner countries is that all countries report trade on a consignment basis. ${ }^{4}$ This shift is thought capable of side-stepping conceptual difficulties in other systems and differences in recording middleman transactions by partner countries to any transaction. The IMF, which, at this writing, is asking for records of the merchandise categories of the balance of payments on a purchase-sale basis, is considering the advantages of using the consignment basis for allocating merchandise transactions by region, while retaining the "change in ownership" basis for establishing the fact of a transaction.

An accompanying proposal of the U.N. is that countries change to what is in effect a general trade classification system, or at least some approximation to it. The system would include for exports separate detailed records on domestic exports and re-exports; for imports, publication either separately or in one category of imports for consumption, for transportation, imports into storage warehouses, and imports into customs manufacturing warehouses. An alternative would be publication of exports from storage warehouses by country of import, with additional information on time lags between import and re-export. It is also suggested that countries keep complete records of their transit trade. In its comments the IMF makes no criticism and apparently is in accord with these proposals.

International Conference Relating to Economic Statistics, Annex 1: External Trade Statistics, League of Nations, Document 6.606(1) M184(2) 1928 II, Geneva, November 1929.

3 Principles for Statistics of External Trade (comments prepared by the International Monetary Fund), United Nations Document E/CN.3/142/Add. 2, January 23, 1953.

${ }^{4}$ Principles for Statistics of External Trade, 1952, op. cit. 


\section{Comments on the Proposals}

The gist of these proposals is to alter the method of reporting partner countries in the direction of recording physical flows, to increase the coverage of the trade records to include a larger part of the consignment trade, and to take a step in the direction of recording middleman trade. The proposed shift to consignment is reasonable since origin-destination obviously cannot provide complete comparability, given the current coverage and structure of trade systems. The other alternative, the purchase-sale basis, cannot provide comparability unless countries extend their definition of "territory," or shift to a residence basis of recording trade. The U.N. experts consider that any suggested changes in this direction are impractical, though they do not offer any theoretical objections to widening the coverage.

While the proposed measures would go a long way to improve the comparability of partner country records of any transaction, they are not expected to succeed in eliminating discrepancies entirely. Expectations of revealing middleman trade are much weaker. And adoption by trading countries of the proposed adjustments would raise fresh problems to be faced. From the point of view of this paper I will note some of the major limitations of these proposals and indicate a possible solution. This does not infer that the experts are unaware of these limitations in all respects; but the quantitative analysis of middleman trade throws light on their possible importance.

A remaining source of discrepancies resulting from middleman activity, and detracting from comparability, is the consignment from country $A$ to country B, which is entirely in the transit record of B. If, as the U.N. group requests, countries compile data on transit trade, the lack of comparability in basic trade records would not be eliminated; and the analyst would be confronted with the rigorous problem of adjusting the record by distinguishing between the transit trade representing consignment and transit trade representing shipment. Lack of comparability resulting from this difficulty might loom large in comparison of records of Western Europe with those of the rest of the world. The basic record may also include goods going through in "disguised transit," reducing comparability. A third problem, noted by the U.N. group, is rerouting of the consignment while in transit to an agent.

As for uncovering middleman trade, the trade statisticians do not touch on the question of offshore merchanting or activities of multinational concerns. They do not solve the problems raised by the inclusion of middleman trade in the transit record. They make no distinction 5oods exempt from duty, which are included in "regular" trade statistics, although passing through the country for purposes of transport only. 
between the activities of an agent and a principal in middleman trade. And they do not request countries to separate on the import side imports for re-export from imports for consumption. As noted above, the IMF Manual attempts to show part of middleman trade - merchandise transactions abroad - but countries do not respond.

Another type of limitation in these proposals results from the weakness of the consignment method for analytical purposes. It is true that some purposes of analysis are served by this system, but much useful information is lost. For some trade neither the producer, nor the consumer, nor the middleman is recorded. This system lies somewhere between a record of production-consumption and a record of purchase-sale. And it is significant that countries have tended to shift away from a consignment method of reporting imports to an origin method in the period since the League convention of $1928 .^{6}$

United Nations experts, ${ }^{7}$ noting these problems, express the opinion that adjustment of records to an origin-destination basis or to a purchasesale basis is facilitated if records are obtained on consignment-consignment basis, and is more difficult if they are collected on either of the other two systems. Moreover they stress the relative difficulties involved, both conceptual and practical, in using the purchase-sale or origin-consumption system. The first argument is valid, but it requires keeping records by three different systems to satisfy major requirements. The second is not, I believe, of great significance in regard to the import side.

One further difficulty in the consignment system is that when it is used the problem of eliminating discrepancies between partner country records for the same transactions, resulting from the time lag between export and import, requires an international convention. Trade experts have never been greatly concerned with this type of discrepancy, but the IMF has attempted to eliminate it from the balance of payments by requesting countries to adjust their records to a time-of-change-inownership basis. This is theoretically satisfactory when the purchase-sale basis of recording trade is used. But it would pose a difficulty if the IMF were to request countries to enter the merchandise account of the balance of payments on a consignment basis, as suggested by the U.N. experts. There would then be many instances of a consignment without a change in ownership and instances of a change in ownership without a consignment (i.e. a rise in stocks owned by nonresidents). A convention would then be needed to prevent discrepancies resulting from the time lag

${ }^{B}$ See International Trade Statistics, R. G. D. Allen and J. Edward Ely, eds., Wiley, 1953 , p. 121.

TExternal Trade Statistics, United Nations Document, E/CN.3/173, and Annex, January 1954. 
between the exporter's record of consignment and the importer's record of receipt of the same merchandise.

If the IMF should decide to use the consignment basis for allocating merchandise transactions by region, while retaining the "change of ownership" basis for establishing the fact of a transaction, the time lag problem would be reduced but not eliminated. Where there is consignment without sale the adjustment is conceptually satisfactory, although it may not be practically feasible.

For records of an offshore transaction, however, adjustment for time lag would be conceptually impossible whenever the time of the sale from country of production $\mathrm{A}$ to offshore middleman $\mathrm{B}$ differs from the time of sale of the same goods by $B$ to country of consignment $C$. In such a case there is a time difference between A's merchandise balance of payments account of exports to $C$ and C's similar record of imports from $\mathrm{A}$ if the change of ownership basis is used for adjusting these records. It might, of course, be argued that conceptually it is not desirable for the two records to agree. However, if the advantages of complete agreement in records for the two sides to any international transaction are superior to the disadvantages, as specialists generally agree, this problem must be resolved. And the consignment with sale basis would require an international convention to resolve it.

Many ways and means come to mind for extending and modifying the recommendations of the international organizations to reduce sharply most of these limitations. For example, if the recommendations were to be adopted, many of the remaining problems could be solved by two additional proposals: (1) when the country of purchase or sale differs from the country of consignment each country should record both countries in the details of the trade statistics; (2) the major middleman countries should subdivide their re-export records and their transit trade records by those trades which involve consignment upon import to residents of the corresponding middleman countries and those which do not. For the subdivision involving consignment, a cross-classification by SITC groups of re-exports of each commodity should be given, showing countries of consignment on the export side by country of consignment on the import side. This should be given in quantity and value if there is a change in ownership, and in quantity only (or, for approximated values, an identifying symbol) if there is consignment to an agent. Such additional suggestions stand a poor chance of being adopted, not because they would be excessively costly; some additional records would be required in any case if the experts' proposals were adopted. Rather, the middleman countries probably would object to releasing part of this information. If they did object, serious problems of lack of com- 
parability of records will not be solved by the limited proposals of the international organizations.

If these opinions are realistic, it seems to me that the best hope is that more countries will recognize the advantages of reporting trade on a dual basis - by country of origin and by country of purchase. While this would not solve the problem of lack of comparability of records, it would contribute to the analysts' efforts to explain divergences between records and throw more light on the role of middleman transactions in world trade. 